\title{
Man or woman? - perception of gender through costume
}

\author{
Ulla Mannering* \\ The National Museum of Denmark, Copenhagen, Denmark
}

(Received 19 December 2012; accepted 10 January 2013)

\begin{abstract}
Knowledge of Scandinavian costume history is based on information gathered from a large variety of sources. Actual costumes of skin and textiles are off course key finds but also prehistoric iconography offers a unique opportunity for comparative costumes studies. In this article quick guidelines for identification of male and female costumes seen on goilfoil figures dated to the Late Iron Age are presented. Further the recently excavated figuring from Lejre in Denmark is used as an example of how the guidelines can be used and applied to other find categories. Thus, the article offers an alternative interpretation of the figurine as a depiction of a female.
\end{abstract}

Key words: Archaeology; prehistory; iconography; costume; gender

\section{Introduction}

Textiles and costumes constitute important elements of our common cultural heritage. In Scandinavian prehistory, as in many past societies around the world, textiles were used for multiple purposes. Common for the time-consuming endeavor to produce textiles was first and foremost the wish to be comfortable and guard against the climate, but textiles also played a crucial role in expressing an individual's identity. Knowledge of our textile and costume history is hence a key to our understanding of a multitude of human issues and is vital for our interpretations of past societies (Barber 1991, Andersson Strand et al. 2010).

Scandinavia has a very long and impressive tradition for textile and costume research which has its starting point in the wide range of well-preserved archaeological finds originating from many different contexts and time periods (Geijer 1938, Broholm and Hald 1940, Hald 1980, Bender Jørgensen 1986, 1992, Østergård 2004). Information related to costume design and visual appearance is not equally well represented in all prehistoric periods. Especially when dealing with the Scandinavian Late Iron Age, it is necessary to include other sources for costume studies, such as prehistoric iconography. Fortunately, Scandinavia has a wide range of objects, primarily in precious metals and stone, which also include or constitute images of clothed figures. To date no single overview of all these images has been published, and in the archaeological literature, the diverse depictions are often presented individually or grouped according their material or type (Holmqvist 1960, Hauck 1978, Watt 1999a, Simek 2002, Helmbrecht 2011). Other more recent works have attempted to view the iconography with a specific theoretical or interpretational starting point thus reaching yet other conclusions (e.g. Göransson 1999, Danielsson 2007, Hedeager 2012).

In my $\mathrm{PhD}$ dissertation on iconographic costumes and depictions of clothed figures in Scandinavia, I took up the challenge to bridge the gap between archaeological textile research and research into prehistoric iconography (Mannering 2004, 2006, 2008). One of the chief conclusions from this study was that Scandinavian iconography depicting clothed figures can be used for costume studies as has previously been done in other countries (e.g. Müller 2003, Owen-Crocker 2010), and supplement information available from other archaeological sources, in particular, the textiles and costumes themselves.

\section{Textiles and gender}

Knowledge of Scandinavian costume history is primarily based on information garnered from a large variety of grave finds and, in some periods, also bog finds. The identification of the gender of the buried persons is, in most graves, based on the presence of gender specific grave goods like jewellery and weapons, and on rarer occasions on the anthropological analysis of the preserved skeletal material (Sellevold et al. 1984). On this background, it has been concluded that, in the Early Bronze and Late Iron and Viking Ages, costumes in general looked different for male and females (Broholm and Hald 1940, Hägg 1974, 1984, 1991, Iversen 1991), while in the Pre-Roman Iron Age and the Early Medieval period, it is more difficult to identify specific male and female garments. In these periods, it seems as if costume design focused less on segregating the genders (Østergård 2004, Mannering 2011).

\footnotetext{
*Email: ulla.mannering@natmus.dk 
Based on the archaeological finds, it can further be concluded that, gender differences recorded in costume design are primarily based on differences in costume shape and drape, while the textiles used to produce these costumes within a specific time period are highly uniform; a phenomenon which can indeed be observed in the textile finds throughout the entire Scandinavian prehistory (Bender Jørgensen 1986). Especially in the Late Iron and Viking Ages, similar textile types were used for male and female costumes while differences can be recorded in the way various costume items were shaped, combined and worn, in the use of decorations and through the accompanying jewellery/fibulae and other accessories. Fortunately, these are large-scale characteristics that, in most cases, can also be tracked in the iconography.

In my work with the Late Iron Age dress iconography, I developed a methodology and an analytical tool which can be used to record and analyze the numerous details in the depictions, and enable a clear and easy description. This system was then related to features known from the archaeological finds denoting male or female such as specific costume shapes, hairstyles, jewellery and weapons, and thereby creating guidelines for gender and costume identification of iconographical figures.

The primary group of artefacts used for the development of these guidelines is gold-foil figures, which have their chronological peak in the sixth and seventh centuries AD (Watt 1999b, p. 138), but also clothed figures on the slightly earlier bracteates, and figures on contemporary or later weapons, jewellery and tapestries were included (Mannering 2006). Thus, it has been possible to make an iconographic costume sequence covering a period of more than 600 years from the fifth to sixth centuries that can be compared with the archaeological textile and costume finds.

\section{Images and dress}

Gold-foil figures may depict one or two figures. In double gold-foil figures, it is characteristic that one of the figures wears more and longer costume items and has longer hair than the other figure depicted. Combined with information on the occurrence of jewellery and necklaces, the following general characteristics may be listed:

- Women generally wear more costume items than men;

- Women generally wear longer costume items than men;

- Women most often wear dresses;

- Women often have long hair, and longer hair than men;

- Women can wear their hair in a knot at the nape of the neck;

- Women usually wear jewellery such as fibulae and necklaces;
- Men usually wear trousers or have clearly delineated legs;

- Men often have short hair.

Among the several hundred different double gold-foil figures, only very few display figures with similar features (Stamsø Munch et al. 2003, p. 249), while this occurs more commonly in the other object categories studied. When only a single figure is depicted, which occurs among the gold foils but also in the jewellery group, it is more difficult to determine costume and gender, but in general the same characteristics may be used. A noteworthy exception is a group of single gold-foil figures for which these guidelines are not sufficient to make a secure gender determination, either because the costume is not very gender specific or because the figure contains contradictory features. Thus these figures have previously been defined as gender neutral (Watt 2004, pp. 189-192). Their presence emphasizes that, the same object category may express different relationships to the body and various ways of depicting human figures.

A typical iconographic female outfit consists of an overgarment and an undergarment (Figure 1). Jewellery is occasionally seen as well. The overgarment consists of different types of capes or, in rare instances, a sleeved

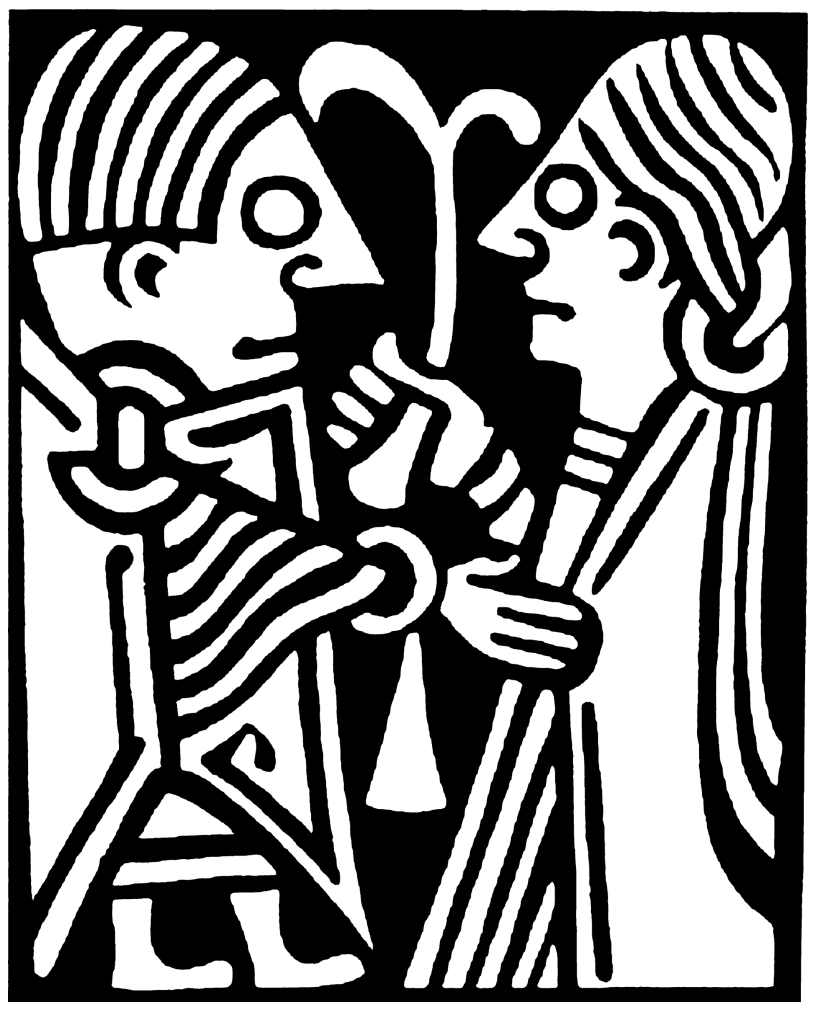

Figure 1. Double gold-foil figure from Hauge in Norway showing a male clad in cloak and tunic and a female clad in cape and dress (C) Ulla Mannering). 


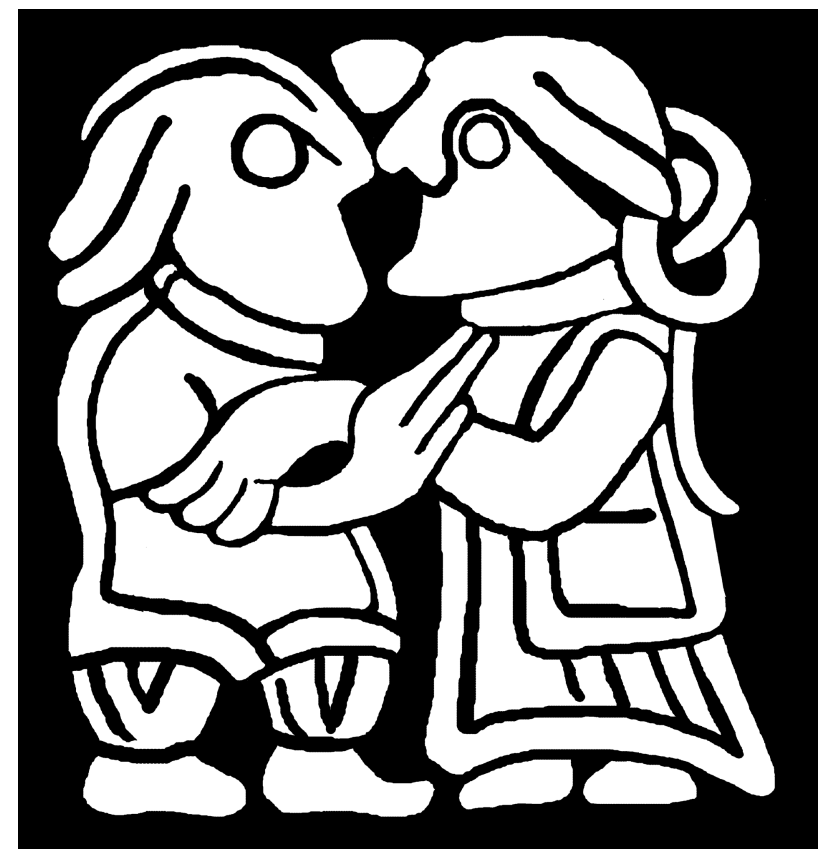

Figure 2. Double gold-foil figure from Helgö in Sweden showing a male clad in tunic and trousers and a female clad in sleeved jacket and dress (C) Ulla Mannering).

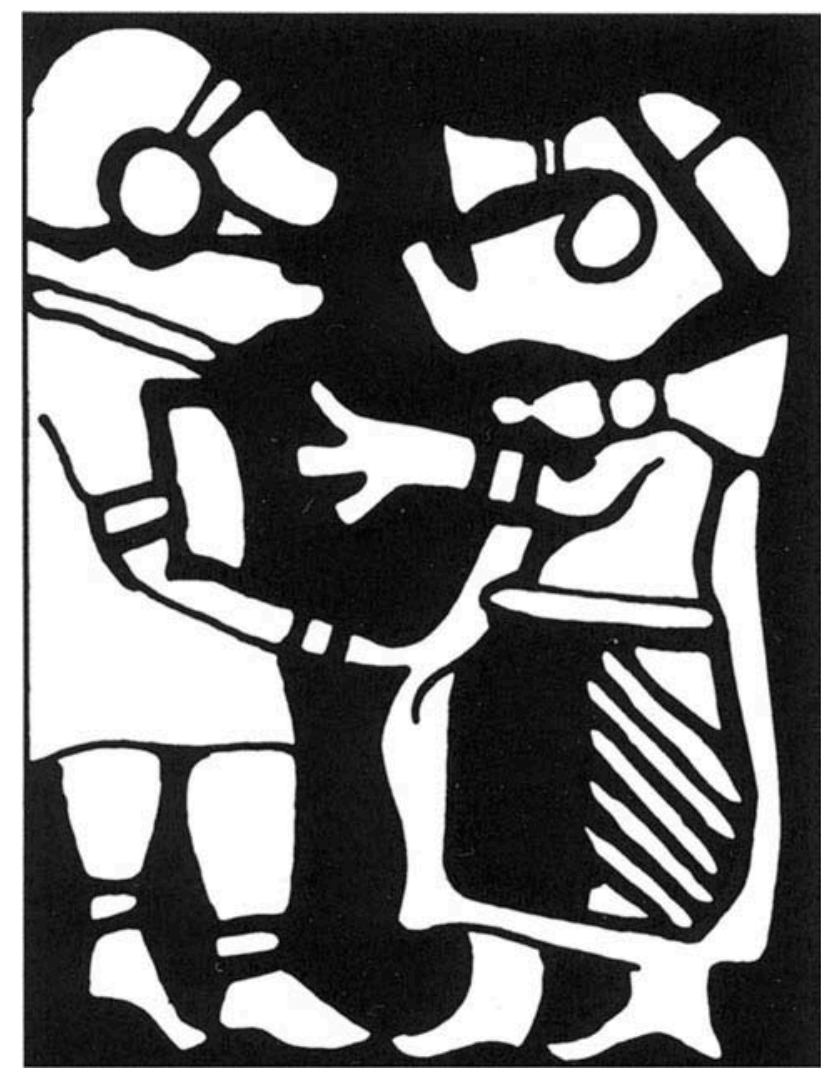

Figure 3. Double gold-foil figure from Slöinge, Halland in Sweden showing a male clad in tunic and trousers and a female clad in blouse and skirt, and a cap on the head (drawing by Anders Andersson).

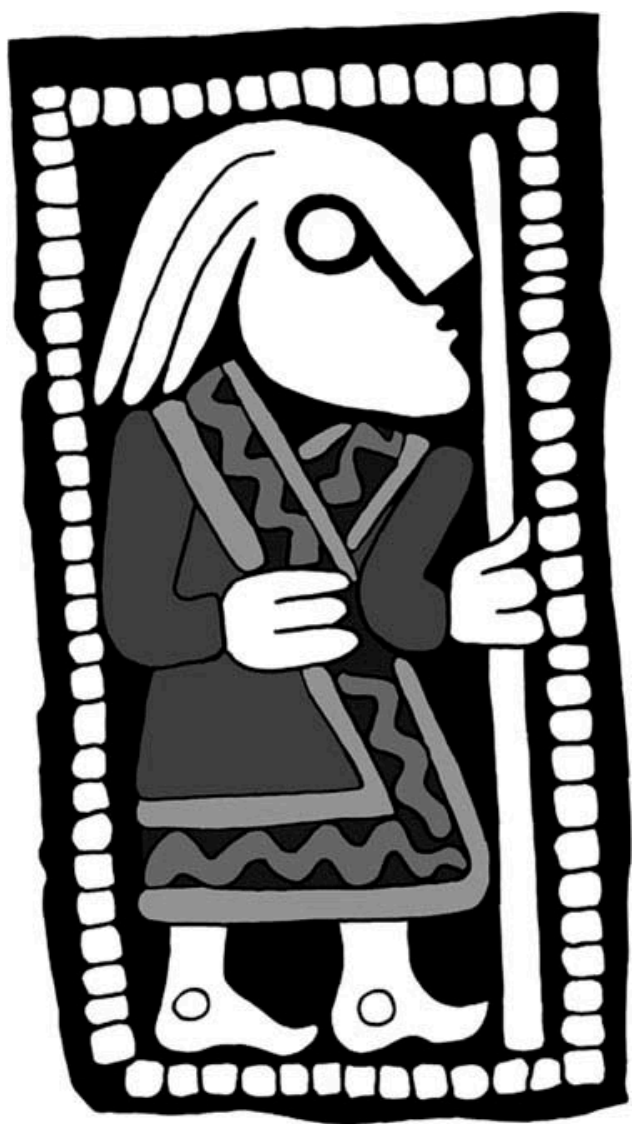

Figure 4. Single gold-foil figure from Sorte Muld, Bornholm in Denmark clad in caftan. Drawing by Sidsel Frisch.

jacket (Figure 2), while the undergarment usually consists of an ankle-length dress. In a few instance, skirts and blouses also occur (Figure 3). The female cape is almost always worn in a symmetrical manner resting on both shoulders which makes it open at the front, although it can be closed directly beneath the chin.

A male outfit generally consists of fewer components. The most common item is a hip-length or knee-length tunic with perhaps a pair of trousers with tight or wide trouser legs (Figure 3). If a man is wearing an overgarment, termed a cloak, the shape differs from those seen on women. The male cloak is most often worn in an asymmetrical manner resting on one shoulder which gives it a distinct pointed look (Figure 1). Another typical male overgarment is the caftan which is characterised as a sleeved garment with oblique front edges and a straight lower edge, and open in the front. The garment's edges are often decorated with wide patterned borders. The caftan is worn exclusively by male figures and is considered to be a warrior's outfit (Figure 4). The terminology chosen to describe the costumes recorded in the iconography is purely based on known modern words and is selected primarily to secure an easy description and identification. 


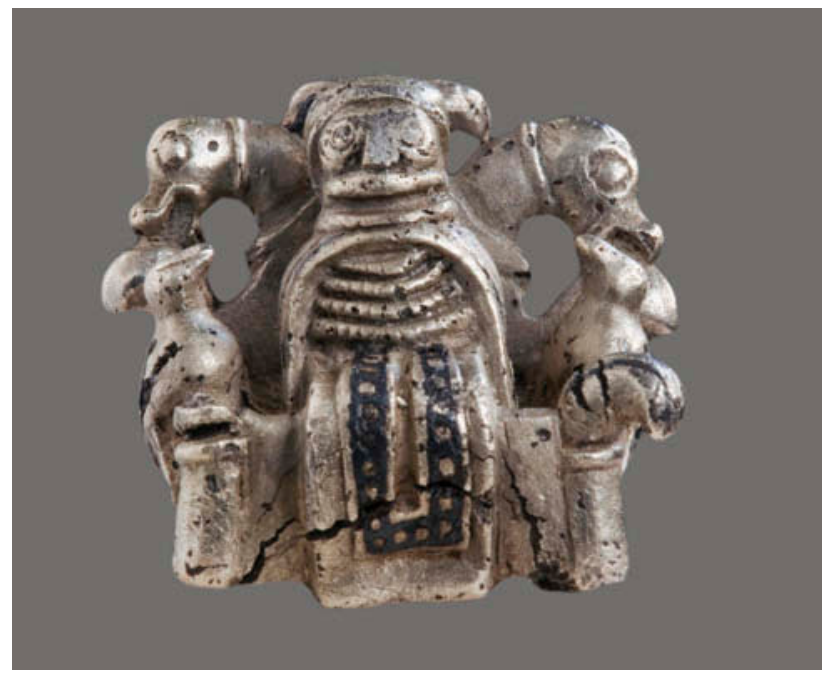

Figure 5. The Lejre figurine (C Roskilde Museum/Ole Malling).

Based on the analysis of over 1000 depictions of figures clad in various outfits dated to the Late Iron Age and Viking Age, it is possible with this methodology and guidelines to evaluate and identify costumes recorded on other iconographic objects.

\section{The Lejre figurine}

In 2009, Roskilde Museum in Denmark recovered a remarkable find by means of a metal-detector during one of its many excavations in Lejre on Zealand (Figure 5). A three-dimensional figurine, a mere few centimetres tall, cast in silver that can be seen from all four sides (http://www.roskildemuseum.dk/Default.aspx? $\mathrm{ID}=306$ ). The figurine depicts an individual seated on a square throne with legs, armrests, and a tall backrest. The back of the figure is placed close to the tall backrest but it is only the bent legs that touch the seat of the throne. The head of the person depicted is not particularly detailed and the face is indicated by two large round eyes and an almost square three-dimensional nose. The mouth is not evident, and instead, a ring passing from one side of the head to the other is seen where the mouth should have been. Underneath this ring at a slight distance is another ring which marks the transition to the torso, but it does not continue all the way around the back of the head (Christensen 2010a, p. 150). The forehead and the back of the head have a round finish without any further characteristics such as ears or hair indicated. The transition from face to forehead is marked by another ring which finishes where the upper face ring also terminates.

The body of the figure is divided into different zones with various patterns and shapes which most likely represent different elements of dress and possibly jewellery. The top garment rests on the shoulders. It is closed beneath the chin but from there it opens up and follows the sides of the figurine and covers the back. The front edge of this dress item is rounded. On either side of this garment, an incised line further emphasizes the edge, but otherwise, the surface is smooth. On the chest, visible beneath the top garment, four slightly curving lines of small dots lie one above the other.

The lower part of the body has quite a square shape which bends and follows the contours of the seat. At this part of the figurine the costume item has a smooth surface and ends in a straight horizontal line without any indication of shoes or feet. From the lowest row of dots and reaching almost to the lower edge of the garment, an oblong decoration/item is visible. This consists of a Ushaped border with a pattern of dots enclosed by a rounded edge. An inlay of niello further enhances the pattern. It is difficult to ascertain if this is a separate costume item or a decoration belonging to the lower garment. The figurine is without arms, with a bird seated on either side. This figurine is stylistically dated to c. AD 950 (Christensen 2010a, p. 143), and even though the figurine is three-dimensionally modelled, it is reminiscent of many other contemporary two-dimensional figurative representations dated to the same period.

\section{Interpretation of the figurine as a male}

Due to its unique character, from the outset, this figurine was the subject of much media attention. It was soon named 'Odin from Lejre', as the excavators interpreted the figurine as representing a man, or rather, the Nordic god Odin seated on his throne together with his two ravens (Christensen 2010a, b, c). Today, this name is firmly rooted and replicas are sold with this label.

In the first descriptions of the Lejre figurine, the identification of the figure was primarily focused on characteristics 
linked to the throne and the head. Depictions of human figures dated to the Late Iron and Viking Ages are iconic in the sense that they do not reveal personal details, and faces and limbs are rarely particularly detailed or even anatomically correctly depicted. Therefore, facial detail can only be used to differentiate between males and females on rare occasions, for instance where a clear moustache or beard is depicted. On the Lejre figurine, the upper face ring has been interpreted as a moustache. The upwards pointed end on one of the sides has been used as an argument for this interpretation (Christensen 2010a, pp. 149-150), but in fact this feature is not evident when the published photographs are studied. Compared to other depictions of males with a moustache, this execution is rather crude and not at all evident, and, in my opinion, this ring cannot be interpreted as a beard and thus is not a usable marker of the gender.

Another feature that has been utilized in gender identification is the shape of the head, which has been interpreted as that of a helmet (Christensen 2010a, pp. 149-150). A sketch published in 2010 (Christensen 2010a, fig. 8) also emphasises a pointed shaped head, but in this case too, the shape cannot be confirmed when compared with the available photos. The shape of the head is indeed much more rounded and does not justify comparison with a helmet. Regrettably, the Lejre figurine has no indication of hair, which in many other cases can be used as a marker of gender. On a group of gold-sheet figures found on the Slöinge settlement in Halland, Sweden (Lamm 2004), woman are sometimes depicted with a small cap or a hairnet (Figure 3). Based on this comparison, the Lejre figurine could just as easily be interpreted as wearing a cap. Therefore, no clear identification of the gender can be made based solely on the characteristics of the head.

A third argument that has been employed to identify the figure as a male is that it was said to be wearing a caftan or a long tunic (Christensen 2010a, pp. 146-149). According to the above-mentioned analyses, the caftan is a highly distinct item of costume which is only associated with a highly exclusive group of depictions related to the male sphere (Figure 4). On the other hand, the characteristics listed for the caftan do not match the appearance of this costume or any of the other costume items combined with this garment. The other option as a long male tunic is equally unlikely, as the costume clearly consists of several different items, which is a typical female feature, and as only in rare occasions are men depicted wearing long garments. Altogether, there are no clear features that support an interpretation of the costume, either as that of a caftan or as a long male tunic.

\section{Interpretation of the figurine as a female}

On the basis of the characteristics outlined above, I suggest that the seated individual on the throne is a woman. Most elements in the costume fit into the categories classified as belonging to women, whereas only the highly uncertain ones fit into the equivalent male categories. The overgarment accords in all aspects with the description of the typical female costume termed a cape, which may be closed under the chin, but always opens to the sides (Mannering 2006, pp. 22-30). In the gold-foil figures, which are most often shown in expanded profile, this type of cape is depicted with a triangular shape (Figures 1 and 6). Male figures, on the contrary, seldom wear overgarments such as cloaks or caftans, and these always have different shapes to the female overgarments, and are fastened in a different way (Figure 1).

It is less easy to identify the garment or garments seen beneath the cape, and several different interpretations are possible. Most likely, it is a dress, which is the most common female costume item in the iconography. Less commonly occurring in costume iconography is the combination of a skirt and a blouse (Figure 3), which is known from a few gold-sheet figures from Sweden (Mannering 2006, p. 215). Furthermore, the fact that the undergarment depicted on the Lejre figurine is so long that the feet are not visible, is yet another feature closely linked to female iconography, and especially seen on figurines dated to the Viking Age. Men, on the other hand, are usually depicted with visible legs/trousers and feet/shoes.

The costume item or decoration visible on top of the dress/skirt on the front of the figurine is an element which in iconographic costume terminology is termed an 'apron' (Mannering 2006, p. 215). This garment feature is known from a number of gold-foil figures from, for instance Slöinge (Figure 6) and Helgö in Sweden, and Sorte Muld in Denmark, and can also be compared with details seen on several Danish and Swedish figurine pendants (Melle 1725/1997, Watt 2001, Lamm 2004). The function of the apron is not fully evident and regrettably, a costume item that matches this position and use has yet to be identified among the archaeological textile and costume finds. There is no doubt, however, that the apron is an element that in Scandinavian iconography is restricted to women.

The transverse grooves evident on the chest of the figurine constitute a very clearly depicted element, but based on known iconographical comparisons, this probably does not represent a costume item. More likely, the dotted lines represent bead chains. Rows of bead chains are a characteristic feature depicted on many contemporaneous female figurines. A well-known example is seen on the pendant from Hagebyhöga in Sweden (Figure 7), where the chest of the woman is adorned with four lines of dots, interpreted as bead necklaces (Arne 1932, Axboe 1986). Bead necklaces belong to the group of female jewellery, which is well documented in the archaeological finds. On the other hand, it has been suggested that, on rare occasions, magnificent and intricate gold neck-rings like the one known from Alleberg and Möne in Sweden (Holmqvist 1960, pp. 102-105) are also 


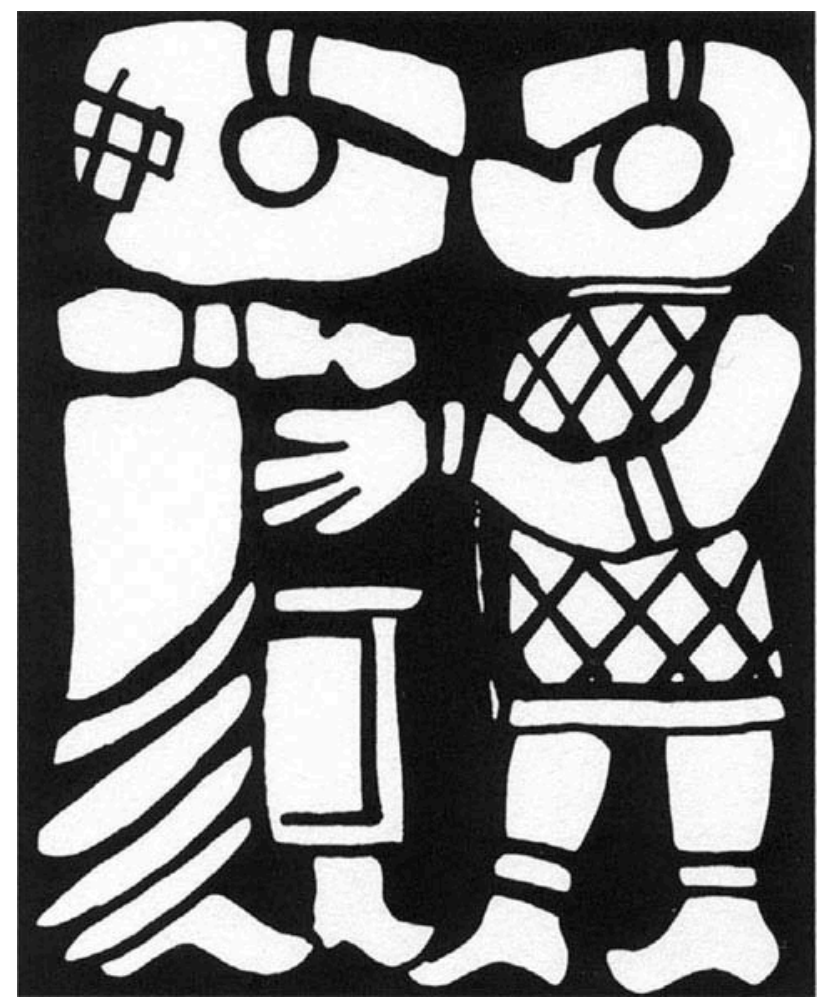

Figure 6. Double gold-foil figure from Slöinge, Halland in Sweden showing a female clad in cape and apron, and a cap on the head, and a male clad in tunic and trousers. Drawing by Anders Andersson.

depicted on male figurines, as on the carved wooden statue from Rude Eskildstrup in Denmark (Kjærum and Olsen 1990, pp. 140-141). It has further been suggested that, the line/ring marking the top edge of the overgarment could be a heavy gold ring, but in my opinion none of these interpretations are fully convincing.

Finally, another, but less likely interpretation of the ornament on the chest is that, this indicates a kind of blouse linked to the occurrence of a skirt, or possibly a chain mail. Especially the last option is, in my opinion, highly unlikely as depictions of chainmail are never combined with other costume items, and secondly, the depictions are restricted to specific male warrior iconography as seen on the helmets from Vendel and Valsgärde in Sweden (Stolpe and Arne 1912, Arwidsson 1977, Hauck 1978), a setting which is not comparable to that recorded for the Lejre figurine.

\section{Conclusion}

Based on the afore-listed features and characteristics, I find it most likely that the figurine from Lejre is wearing a female costume, and therefore I also think it is most likely that the figurine depicts a woman.

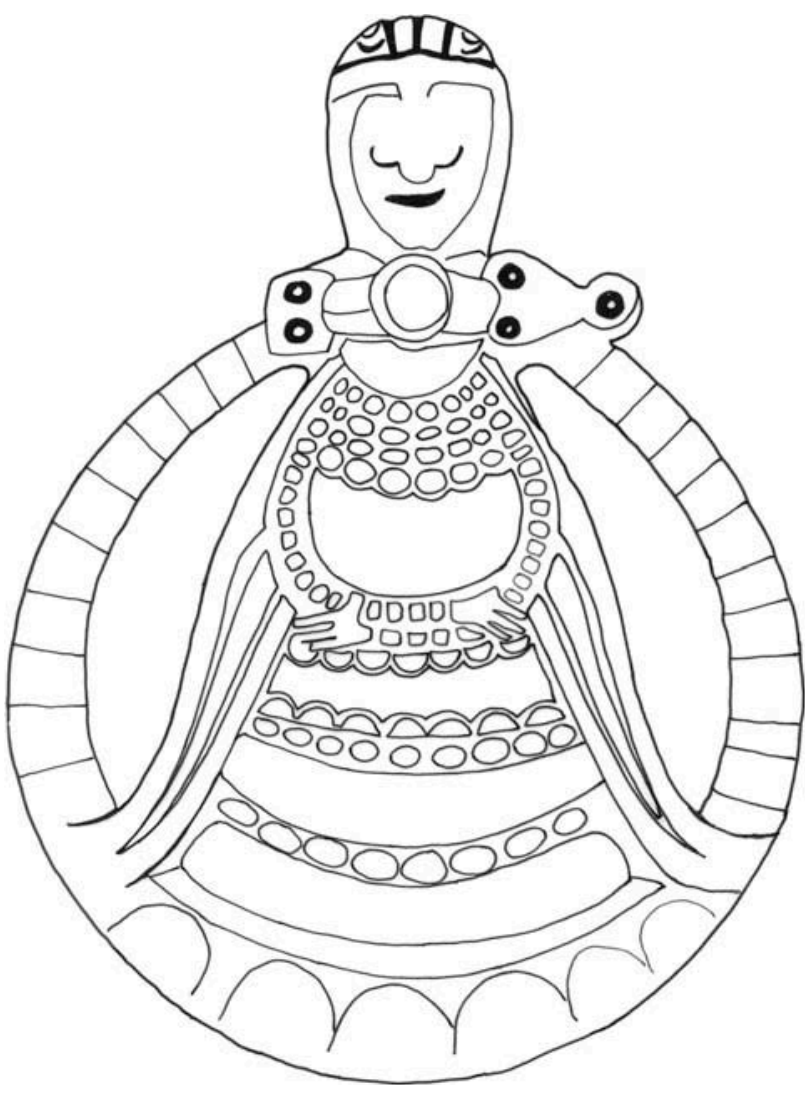

Figure 7. Pendant from Hagebyhöga in Sweden. Drawing by Pernille Foss, after Axboe (1986).

That two researchers, viewing the same object, can reach such different conclusions is due to our analyses giving weight to quite different elements. The birds, who turn into Hugin and Munin (the ravens of Odin), and the chair, seen as Lidskjalv (the throne of Odin, from where he can see all nine worlds), are central elements in the identification of the figurine as Odin. An identification, which places it in a mythological universe where everything is possible (e.g. Andrén et al. 2006).

On the other hand, the signs of gender revealed by the costume cannot be considered secondary to the other details. Within Nordic mythology, there are many examples of strong and powerful women, who could also have been depicted in this way (Näsström 1998, 2009). A further and perhaps more provocative possibility could be that, here, we see Odin depicted in female attire. A disguise, both Odin and Thor were famed for using. Hence, we should even be open to the fact that other interpretations of the figurine than merely as Odin or a woman are possible. Further, it has been pointed out that in a prehistoric context it may be delimiting only to consider the presence of two genders and that the Lejre figurine as a 'performing object' can be used for many different interpretations (Danielsson 2010, p. 31). 
Based on the presented evidence there is no doubt that a large part of the Scandinavian iconography depicting clothed human figures can be used for costume studies, and that they depict what was physically and visually available and preferred in Late Iron Age society. The majority of costumes identified in the costume iconography have also been identified in the archaeological textile record, and thus, the images constitute a reliable source for research in both iconographical and archaeological dress. In this way, the Scandinavian costume iconography contributes with crucial new information on chronological, regional, and social differences in costume traditions and lifestyles in the Late Iron Age which can be used by all researchers and applied to new finds.

\section{References}

Andersson Strand, E., Frei, K.M., Gleba, M., Mannering, U., Nosch, M.-L. and Skals, I., 2010. Old textiles - new possibilities. European Journal of Archaeology, 13 (2), 149-173.

Andrén, A., Jennbert, K., and Raudvere, C., eds., 2006. Old Norse religion in long-term perspectives. In: Origins, changes, and interactions. An international conference in Lund, Sweden, June 3-7, 2004. Lund.

Arne, T.J., 1932. Ein Bemerkenswerter Fund in Östergötland. Acta Archaeologica, 3. 67-112.

Arwidsson, G., 1977. Valsgärde 7. Lund: Berlingska Boktryckeriet.

Axboe, M., 1986. Brísingamen - også et arkæologisk problem. Danske Studier, 116-121.

Barber, E.J.W., 1991. Prehistoric textiles. The development of cloth in the Neolithic and bronze ages. Princeton University Press.

Bender Jørgensen, L., 1986. Forhistoriske textiler $i$ Skandinavien. Prehistoric Scandinavian Textiles, Nordiske Fortidsminder Serie B, Bind 9, Det Kongelige Nordiske Oldskriftselskab, Copenhagen.

Bender Jørgensen, L., 1992. North European textiles until AD 1000. Aarhus: Aarhus University Press.

Broholm, H.C. and Hald, M., 1940. Costumes of the bronze age in Denmark. Copenhagen: Nyt Nordisk Forlag.

Christensen, T., 2010a. En sølvfigurin fra Lejre i Danmark. Viking, 2010, Bind LXXIII, 143-156.

Christensen, T., 2010b. Odin fra Lejre. ROMU, 2009, 219-230.

Christensen, T., 2010c. Gud, Konge eller ...?. Arkceologisk Forum, 22, 21-25.

Danielsson, I.-M.B., 2007. Masking moments. The transitions of bodies and beings in late Iron Age Scandinavia. Stockholm Studies in Archaeology 40. Stockholm University.

Danielsson, I.-M.B., 2010. Liten lurifax I Lejre. Arkceologisk Forum, 22, 30-33.

Geijer, A., 1938. Birka III. Die Textilefunde aus den Gräbern. Uppsala: Almqvist och Wiksells boktryck.

Göransson, E.-M., 1999. Bilder av kvinnor och kvinnlighet. Genus och kroppsspråk under övergången till kristendomen. Stockholm Studies in Archaeology 18. Stockholm University.

Hägg, I., 1974. Kvinnodräkten i Birka. Livplaggens rekonstruktion på grundlag av det arkeologiska materialet. AUN 2. Archaeological Studies. Uppsala: Archaeological Institute.

Hägg, I., 1984. Die Textilreste aus dem Hafen von Haithabu. Berichte Haithabu 20. Neumünster: Karl Waccholtz Verlag.

Hägg, I., 1991. Textilfunde aus der Siedlung und aus den Gräbern von Haithabu. Berichte Haithabu 29. Neumünster: Wachholtz.
Hald, M., 1980. Ancient Danish Textiles from Bogs and Burials. Publications of the National Museum of Denmark. Archaeological-Historical Series Vol. XXI. Copenhagen.

Hauck, K., 1978. Bildforschung als Historische Sachforschung. Zur vorchristlichen Ikonographie der figuralen Helmprogramme aus der Vendelzeit. In: K. Hauck and H. Mordek, eds. Geschichtsschreibung und Geistiges Leben im Mittelalter. Cologne Böhlau, 27-70.

Hedeager, L., 2012. Iron age myth and materiality. An archaeology of Scandinavia AD 400-1000. New York, NY: Routledge.

Helmbrecht, M., 2011. Wirkmächtige Kommunikationsmedien. Menschenbilder der Vendel- und Wikingerzeit und ihre Kontexte. Acta Archaeologica Lundensia Series Prima in $4^{\circ}$, No. 40. University of Lund.

Holmqvist, W., 1960. The dancing gods. Acta Archaeologica, 31, 101-127.

Iversen, M., ed., 1991. Mammen. Grav, kunst og samfund $i$ vikingetid. Jysk Arkæologisk Selskabs Skrifter XXVIII. Højbjerg.

Kjærum, P. and Olsen, R.A., eds., 1990. Oldtidens ansigt. Faces of the Past. Festskrift til Dronning Margrethe II. Det kongelige Nordisk Oldskriftselskab, Jysk Arkæologisk Selskab. Copenhagen.

Lamm, J.P., 2004. Figural gold foils found in Sweden: a study based on the discoveries from Helgö. In: B. Gyllensvärd, P. Harbison, M. Axboe, J.P. Lamm, T. Zachrisson, and S. Reisborg, eds. Excavations at Helgö XVI. Exotic and sacral finds from Helgö. Stockholm: Almqvist \& Wiksell International, 41-142.

Mannering, U., 2004. Dress in Scandinavian Iconography of the 5th-10th centuries A.D. In: J.Maik, ed. Priceless Invention of Humanity - Textiles, NESAT VIII. Acta Archaeologica Lodziensia Nr. 50/1. Łódz, 67-74.

Mannering, U., 2006. Billeder af dragt. En analyse af påkloedte figurer fra yngre jernalder $i$ Skandinavien. Dissertation (PhD). University of Copenhagen.

Mannering, U., 2008. Iconography and costume from the Late Iron Age in Scandinavia. In: M.Gleba, C. Munkholt, and M.-L. Nosch, eds. Dressing the past. Oxford: Oxbow Books, 59-67.

Mannering, U., 2011. Early Iron Age craftsmanship from a costume perspective, Arkceologi $i$ Slesvig/Archäologie in Schleswig, Sonderband „Det 61. Internationale Sachsensymposion 2010“ Haderslev, Danmark, 85-94.

Melle, J. von, 1725/1997. Commentatiuncula de simulachris aureis, quæ inBornholmia, maris balthici insula, agris eruuntur. Translation. In: J.Sørensen, E. Thykier, and M. Watt, eds. Jacob von Melle og de Bornholmske guldgubber. Rønne: Colbergs Boghandel.

Müller, M., 2003. Die Kleidung nach Quellen des frühen Mittelalters. Berlin Walter de Gruyter.

Näsström, B.-M., 1998. Frøya. Den stora gudinnen i Norden. Oslo: Pax.

Näsström, B.-M., 2009. Nordiska gudinnor. Nytolkningar av den förkristna mytologin. Stockholm: Bonnier.

Østergård, E., 2004. Woven into the Earth. Textiles from Norse Greenland. Aarhus: Universitetsforlag.

Owen-Crocker, G., 2010. Dress in Anglo Saxon England. Revised and enlarged edition. Woolbridge: The Boydell Press.

Sellevold, B.J., Hansen, U.L. and Jørgensen, J.B., 1984. Iron age man in Denmark. Prehistoric man in Denmark. Nordiske Fortidsminder Serie B, Bind 8, Det Kongelige Nordiske Oldskriftselskab, Copenhagen.

Simek, R., 2002. Goddesses, mothers, disir: iconography and interpretation of the female deity in Scandinavia in the first millennium. In: R. Simek and W. Heizmann, eds. 
Mythological woman. Studies in memory of Lotte Motz. Vienna Fassbaender, 93-123.

Stamsø Munch, G., Johansen, O.S., and Roesdahl, E., eds., 2003. Borg in Lofoten: a chieftain's farm i North Norway. Bøstod: Tapir Academic Press.

Stolpe, H.J. and Arne, T.J., 1912. Gravfältet vid Vendel. Stockholm: K.L. Beckmans Boktryckeri.

Watt, M., 1999a. Kings or gods? Iconographic evidence from Scandinavian gold foil figures. Anglo-Saxon Studies in Archaeology and History, 10, Oxford, 173-183.

Watt, M., 1999b. Gubber. Reallexikon der Germanischen Altertumskunde, 13, 132-142.
Watt, M., 2001. "Gummor" og "grodor". Om kønsbestemmelse af guldgubber. In: B. Magnus, C. Orrling, M. Rasch, and G. Tegnér, eds. Vi fär tacka Lamm. Stockholm: Statens Historiska Museum, 219-228.

Watt, M., 2004. The Gold-Figure Foils ("Guldgubbar") from Uppåkra. In: L.Larsson, ed. Continuity for centuries. A ceremonial building and its context at Uppåkra, Southern Sweden. Uppåkrastudier 10. Acta Archaeologica Lundensia, Series 8, No. 30. Lund: Almqvist \& Wiksell International, 167-221. 